\title{
What is needed to guide testing for anorectal and pharyngeal Chlamydia trachomatis and Neisseria gonorrhoeae in women and men? Evidence and opinion
}

\author{
Nicole H. T. M. Dukers-Muijrers ${ }^{1,2^{*}+}$, Julius Schachter ${ }^{3 \dagger}$, Genevieve A. F. S. van Liere ${ }^{1,2}$, Petra F. G. Wolffs ${ }^{2}$
} and Christian J. P. A. Hoebe ${ }^{1,2}$

\begin{abstract}
Background: Anorectal and pharyngeal infections with Chlamydia trachomatis (CT) and Neisseria gonorrheae (NG) are commonly observed in men who have sex with men (MSM). There is increasing evidence that such infections at extragenital sites are also common in women. In both sexes, these infections are largely overlooked as they are not routinely tested for in regular care. Testing based on sexual behavior or symptoms would only detect half of these extra-genital infections. This paper elucidates the differences and similarities between women and MSM, regarding the epidemiology of extra-genital CT and NG. It discusses the clinical and public health impact of untested extra-genital infections, how this may impact management strategies, and thereby identifies key research areas.

Discussion: Extra-genital CT is as common in women as it is in MSM; NG in women is as common at their extragenital sites as it is at their genital sites. The substantial numbers of extra-genital $C T$ and NG being missed in women and MSM indicate a need to test and treat more patients and perhaps different choices in treatment and partner management strategies. Doing so will likely contribute to reduced morbidity and transmission in both sexes. However, in our opinion, it is clear that there are several knowledge gaps in understanding the clinical and public health impact of extra-genital CT and NG. Key research areas that need to be addressed concern associated morbidity (anorectal and reproductive morbidity due to extra-genital infections), 'the best' management strategies, including testing and treatment for extra-genital $C T$, extra-genital treatment resistance, transmission probabilities between partners and between anatomic sites in a woman, and impact on transmission of other infections. Data are also lacking on costeffectiveness of pharyngeal testing, and of NG testing and anorectal CT testing in women. Gaps in the management of extra-genital CT and NG may also apply for other STIs, such Mycoplasma genitalium.
\end{abstract}

Summary: Current management strategies, including testing, to address extra-genital CT and NG in both sexes are suboptimal. Comparative data on several identified key themes in women and MSM are lacking and urgently needed to guide better management of extra-genital infections.

Keywords: Extra-genital, Chlamydia trachomatis, Neisseria gonorrhoeae, Women, MSM

\footnotetext{
* Correspondence: nicole.dukers@ggdzl.nl

${ }^{\dagger}$ Equal contributors

'Department of Sexual Health, Infectious Diseases and Environmental Health,

South Limburg Public Health Service, Geleenbeeklaan 2, 6166 GR

Sittard-Geleen, The Netherlands

${ }^{2}$ Department of Medical Microbiology, School of Public Health and Primary

Care (CAPHRI), Maastricht University Medical Centre (MUMC+), Maastricht,

The Netherlands

Full list of author information is available at the end of the article
}

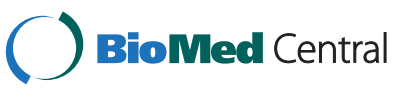

(C) 2015 Dukers-Muijrers et al. Open Access This article is distributed under the terms of the Creative Commons Attribution 4.0 International License (http://creativecommons.org/licenses/by/4.0/), which permits unrestricted use, distribution, and reproduction in any medium, provided you give appropriate credit to the original author(s) and the source, provide a link to the Creative Commons license, and indicate if changes were made. The Creative Commons Public Domain Dedication waiver (http://creativecommons.org/publicdomain/zero/1.0/) applies to the data made available in this article, unless otherwise stated. 


\section{Background}

It is a continuous challenge to control the spread of sexually transmitted infections (STIs). Chlamydia trachomatis (CT) and Neisseria gonorrhoeae (NG) are sexually transmissible bacteria that may result in serious complications such as pelvic inflammatory disease, infertility and ectopic pregnancy in women, and epididymitis in men and play an important role in enhancing HIV transmission [1, 2]. The Centers for Disease Control and Prevention (CDC) reported about 1.4 million new CT infections in 2013 and numbers are still increasing each year [3]. In Europe, the number of $\mathrm{CT}$ infections is increasing with more than 250000 new cases reported each year [4].

The use of highly sensitive and specific laboratory assays, i.e. nucleic acid amplification tests (NAAT), has revealed the frequent presence of CT and NG at extra-genital sites. Infections at extra-genital sites are common in both men who have sex with men (MSM) and women. In MSM, this led to specific control guidelines, including expanded testing [5-9]. In women, such guidelines are beginning to emerge. However, the occurrence of extra-genital infections also has led to international debate on the (need for) control of such infections by testing and treatment.

This paper addresses the state of the art in extra-genital NG and CT epidemiology, elucidating the differences and similarities in women versus MSM, argues how this may impact control strategies, and identifies the knowledge gaps to address these issues to guide testing.

\section{Epidemiology of extra-genital STI in women and MSM}

To provide an overview on state-of-the-art on the prevalence and anatomic site distribution of CT and NG infections in women, we have reviewed the literature focusing on including studies (in English) in women describing anorectal and/or pharyngeal CT and NG infections detected using NAATs. We conducted a Medline search (last update 8 June 2015) using the terms: ('women or woman or female') and ('chlamydia,' 'gonorrhea' or 'gonorrhoeae'). These terms were used in combination with ('anorectal or rectal or anal') or ('oropharyngeal or pharyngeal or oral') or ('extra-genital'). Additionally, relevant results on anorectal CT that could not directly be retrieved from these papers were kindly provided by the authors of these studies. We compared results to findings in several key papers in MSM from different countries and using NAAT. Because there is an abundant literature on extra-genital infections in MSM a literature search was deemed not necessary.

\section{Prevalence}

Prevalence, which is defined here as the proportion of the study population that tested positive, has so far for women only been assessed in clinic-based populations. The observed prevalence ranges of extra-genital CT as detected by NAAT are notably similar between women [10-32] and MSM [11, 18, 24, 25, 32-39], ranging between 1 and $3 \%$ for pharyngeal CT and 1-18 \% for anorectal CT (see Table 1). Of note, MSM who define themselves as being heterosexual (e.g. male swingers) have appreciable numbers of anorectal infections as well [11]. Pharyngeal CT and NG prevalences in heterosexual men are similar to that seen in women (e.g. $[11,28])$. Overall however, data in heterosexual men are scarce.

Most studies on anorectal CT (see Table 2) have included women tested on indication of receptive anal intercourse (RAI). Few studies reported systematic testing of all women, i.e. testing irrespective of reported behavior or symptoms [10-12, 27]. Most studies were done in women attending care services; one study reported on women testing by self-triage via the Internet [14] and another study reported on women in the 'open population' reached via friends in their social network [31]. Comparable prevalence ranges in the tested populations were reported across studies. It was notable that some geographic variation might be present. Excluding two studies that tested on indication of genital CT, prevalences of anorectal CT in most studies in Canada (11.7-13.5 \% ) or US (5.1-27.3\% ) appeared even higher than that of most studies in Europe (5.6-12.5 \% ). Still, we need more representative data from future studies with less selected populations to be able to compare prevalence rates (and associated factors) in women. Such population-based studies are feasible given the high acceptance of self-collection methods for testing.

In MSM in the Netherlands and Germany, lymphogranuloma venereum (LGV) serovars comprised 2-16\% of CT positive anorectal samples and were also found in the pharynx and urethra $[40,41]$. In women, LGV is very unusual, although systematic assessment of LGV in women is scarce [42].

The prevalence of extra-genital NG reflects the well known disparity between MSM and women (see Table 1). The occurrence of NG is at all anatomic sites substantially less frequent in women; women show NG

Table 1 Prevalence of extra-genital Chlamydia trachomatis (CT) and Neisseria gonorrhoeae (NG) in women and in men who have sex with men (ref.: [10-32] for women and [11, 18, 24, 25, 3241] for MSM)

\begin{tabular}{lllllll}
\hline & \multicolumn{3}{l}{ Women } & & & \multicolumn{3}{c}{ Men who have sex with men } \\
\cline { 2 - 3 } & CT & NG & & CT & LGV (of CT+) & NG \\
\hline Pharyngeal & $1-3 \%$ & $1-2 \%$ & & $1-3 \%$ & $9-16 \%$ & $4-12 \%$ \\
Anorectal & $7-17 \%$ & $0-3 \%$ & & $1-18 \%$ & $2-16 \%$ & $6-21 \%$ \\
Genital & $5-13 \%$ & $1-2 \%$ & $3-8 \%$ & $2 \%$ & $3-11 \%$
\end{tabular}

LGV Lymphomgranuloma Venereum 
Table 2 Overview of studies that include anorectal Chlamydia trachomatis (CT) nucleic acid amplification testing in women by routine systematic testing or selective testing on indication of receptive anal sex (RAI) or otherwise

\begin{tabular}{|c|c|c|c|c|c|c|c|c|c|c|c|c|}
\hline & Setting & Population & $\begin{array}{l}\text { Tested } \\
N\end{array}$ & $\begin{array}{l}\text { Anorectal CT } \\
\%(n)\end{array}$ & $\begin{array}{l}\text { Had RAI } \\
\%(n)\end{array}$ & $\begin{array}{l}\text { Not had } \\
\text { RAI \% (n) }\end{array}$ & $\begin{array}{l}\text { Anorectal } \\
\text { CT In } \\
\text { women } \\
\text { with RAl } \\
\%(n)\end{array}$ & $\begin{array}{l}\text { Anorectal } \\
C T \text { In } \\
\text { women } \\
\text { without RAI } \\
\%(n)\end{array}$ & $\begin{array}{l}\text { Genital CT } \\
\%(n)\end{array}$ & $\begin{array}{l}\text { Genital and/ } \\
\text { or anorectal } \\
\text { CT }\end{array}$ & $\begin{array}{l}\text { Single } \\
\text { anorectal CT in } \\
\text { genital and/or } \\
\text { anorectal } \\
\text { positives }\end{array}$ & $\begin{array}{l}\text { Single } \\
\text { anorectal } \\
C T \text { in } \\
\text { anorectal } \\
\text { positives }\end{array}$ \\
\hline & Routine systematic testing & & & & & & & & & & & \\
\hline $\begin{array}{l}\text { van Liere } \\
\text { et al. [10] }\end{array}$ & $\begin{array}{l}\text { STI clinic, } \\
\text { South Limburg, } \\
\text { Netherlands '12-'13 }\end{array}$ & All & 654 & $\begin{array}{l}8.4 \% \\
(55 / 654)\end{array}$ & $\begin{array}{l}31.0 \% @ 6 \\
(203 / 654)\end{array}$ & $\begin{array}{l}69.0 \% @ 6 \\
(451 / 654)\end{array}$ & $\begin{array}{l}7.9 \% \\
(16 / 203)\end{array}$ & $\begin{array}{l}8.6 \% \\
(39 / 451)\end{array}$ & $\begin{array}{l}11.2 \% \\
(73 / 654)\end{array}$ & $\begin{array}{l}11.6 \% \\
(76 / 654)\end{array}$ & $\begin{array}{l}3.9 \% \\
(3 / 76)\end{array}$ & $\begin{array}{l}5.4 \% \\
(3 / 55)\end{array}$ \\
\hline $\begin{array}{l}\text { Van Liere } \\
\text { et al. [11] }\end{array}$ & $\begin{array}{l}\text { STI clinic, } \\
\text { South Limburg, } \\
\text { Netherlands '10-'12 }\end{array}$ & Swingers & 461 & $\begin{array}{l}6.7 \% \\
(31 / 461)\end{array}$ & $\begin{array}{l}29.5 \% @ 6 \\
(136 / 461)\end{array}$ & $\begin{array}{l}70.5 \% @ 6 \\
(325 / 461)\end{array}$ & $\begin{array}{l}3.5 \% \\
(16 / 136)\end{array}$ & $\begin{array}{l}4.6 \% \\
(15 / 325)\end{array}$ & $\begin{array}{l}6.3 \% \\
(29 / 461)\end{array}$ & $\begin{array}{l}7.8 \% \\
(36 / 461)\end{array}$ & $\begin{array}{l}19.4 \% \\
(7 / 36)\end{array}$ & $\begin{array}{l}22.6 \% \\
(7 / 31)\end{array}$ \\
\hline $\begin{array}{l}\text { Peters } \\
\text { et al. [12] }\end{array}$ & $\begin{array}{l}\text { Primary health } \\
\text { care facilities } \\
\text { South Africa '11-'12 }\end{array}$ & All & 603 & $\begin{array}{l}7.1 \% \\
(43 / 603)\end{array}$ & $\begin{array}{l}4.3 \% @ 6 \\
(26 / 603)\end{array}$ & $\begin{array}{l}95.7 \% @ 6 \\
\text { (577/603) }\end{array}$ & $\begin{array}{l}3.8 \% \\
(1 / 26)\end{array}$ & $\begin{array}{l}7.3 \% \\
(42 / 577)\end{array}$ & $\begin{array}{l}16.0 \% \\
(96 / 603)\end{array}$ & $\begin{array}{l}17.7 \% \\
(107 / 603)\end{array}$ & $\begin{array}{l}10.3 \% \\
(11 / 107)\end{array}$ & $\begin{array}{l}25.6 \% \\
(11 / 43)\end{array}$ \\
\hline \multirow[t]{2}{*}{$\begin{array}{l}\text { Ostergaard } \\
\text { et al. [27] }\end{array}$} & $\begin{array}{l}\text { STI clinic, Denmark } \\
\text { '95-'96 }\end{array}$ & All & 196 & $\begin{array}{l}5.6 \% \\
(11 / 196)\end{array}$ & $\begin{array}{l}43.9 \% \text { @e } \\
(86 / 196)\end{array}$ & $\begin{array}{l}56.1 \% @ e \\
(110 / 196)\end{array}$ & $\begin{array}{l}4.7 \% \\
(4 / 86)\end{array}$ & $\begin{array}{l}6.4 \% \\
(7 / 110)\end{array}$ & $\begin{array}{l}14.5 \% \\
(25 / 173)\end{array}$ & $\begin{array}{l}15.6 \% \\
(27 / 173)\end{array}$ & $\begin{array}{l}7.4 \% \\
(2 / 27)\end{array}$ & $\begin{array}{l}18.2 \% \\
(2 / 11)\end{array}$ \\
\hline & Testing on indication of RAl & & & & & & & & & & & \\
\hline $\begin{array}{l}\text { Trebach } \\
\text { et al. [28] }\end{array}$ & $\begin{array}{l}2 \text { public health STI } \\
\text { clinics, Baltimore, USA '11-'13 }\end{array}$ & $\begin{array}{l}\text { Had RAl, } \\
\text { sharing toys }\end{array}$ & 602 & $\begin{array}{l}8.6 \% \\
(52 / 602)\end{array}$ & 100 \% @3 & $0 \%$ & $\begin{array}{l}8.6 \% \\
(52 / 602)\end{array}$ & N/A & $\begin{array}{l}9.4 \% \\
(50 / 532)\end{array}$ & $\begin{array}{l}11.8 \% \\
(63 / 532)\end{array}$ & $\begin{array}{l}25.4 \% \\
(13 / 63)\end{array}$ & $\begin{array}{l}26.0 \% \\
(13 / 50)\end{array}$ \\
\hline $\begin{array}{l}\text { Bachmann } \\
\text { et al. [24] }\end{array}$ & $\begin{array}{l}\text { STI clinics, hospital-based HIV } \\
\text { clinics, USA '03-'07 }\end{array}$ & $\begin{array}{l}\text { Had RAl, STD } \\
\text { contact }\end{array}$ & 99 & $\begin{array}{l}27.3 \% \\
(27 / 99)\end{array}$ & $\begin{array}{l}40.4 \% @ 2 \\
(40 / 99)\end{array}$ & $\begin{array}{l}59.6 \% @ 2 \\
(59 / 99)\end{array}$ & $\begin{array}{l}17.5 b \% \\
(7 / 40)\end{array}$ & $\begin{array}{l}33.9 \% \\
(20 / 59)\end{array}$ & $\begin{array}{l}23.2 \% \\
(23 / 99)\end{array}$ & $\begin{array}{l}30.3 \% \\
(30 / 99)\end{array}$ & $\begin{array}{l}23.3 \% \\
(7 / 30)\end{array}$ & $\begin{array}{l}25.9 \% \\
(7 / 27)\end{array}$ \\
\hline $\begin{array}{l}\text { Van der Helm } \\
\text { et al. [25] }\end{array}$ & $\begin{array}{l}\text { STI clinics, Amsterdam, } \\
\text { South Limburg, } \\
\text { Netherlands, } \\
\text { '06-'07 }\end{array}$ & Had RAl & 901 & $\begin{array}{l}9.3 \% \\
(84 / 901)\end{array}$ & 100 \% @6 & $0 \%$ & $\begin{array}{l}9.3 \% \\
(84 / 901)\end{array}$ & N/A & N/A & N/A & N/A & N/A \\
\hline $\begin{array}{l}\text { Sethupathi } \\
\text { et al. [19] }\end{array}$ & $\begin{array}{l}\text { STI clinic Singleton } \\
\text { hospital, UK '06-'08 }\end{array}$ & $\begin{array}{l}\text { Had RAI, STD } \\
\text { contact, } \\
\text { symptoms, } \\
\text { assault }\end{array}$ & 160 & $\begin{array}{l}12.5 \% \\
(20 / 160)\end{array}$ & $\begin{array}{l}51.2 \% @ u \\
(82 / 160)\end{array}$ & $\begin{array}{l}48.8 \% \text { @u } \\
\text { (78/160) }\end{array}$ & $\begin{array}{l}12.2 \% \\
(10 / 82)\end{array}$ & $\begin{array}{l}12.8 \% \\
(10 / 78)\end{array}$ & $\begin{array}{l}14.1 \% \\
(22 / 156)\end{array}$ & $\begin{array}{l}14.7 \% \\
(23 / 156)\end{array}$ & $\begin{array}{l}4.3 \% \\
(1 / 23)\end{array}$ & $\begin{array}{l}5.0 \% \\
(1 / 20)\end{array}$ \\
\hline $\begin{array}{l}\text { Koedijk } \\
\text { et al. [18] }\end{array}$ & $\begin{array}{l}\text { STI clinics } \\
\text { Netherlands '06-'10 }\end{array}$ & $\begin{array}{l}\text { Had RAl, } \\
\text { symptoms, } \\
\text { prostitution }\end{array}$ & 18,238 & $\begin{array}{l}9.3 \% \\
(1695 / 18,238)\end{array}$ & $\mathrm{N} / \mathrm{A}$ & N/A & N/A & N/A & $\begin{array}{l}9.4 \% \\
(1709 / 18,238)\end{array}$ & $\begin{array}{l}11.7 \% \\
(2139 / 18,238)\end{array}$ & $\begin{array}{l}20.1 \% \\
(430 / 2139)\end{array}$ & $\begin{array}{l}25.4 \% \\
(430 / 1695)\end{array}$ \\
\hline $\begin{array}{l}\text { Hunte } \\
\text { et al. [16] }\end{array}$ & $\begin{array}{l}\text { STI clinic Miami } \\
\text { USA '07 }\end{array}$ & Had RAl & 97 & $\begin{array}{l}17.5 \% \\
(17 / 97)\end{array}$ & 100 \% @3 & $0 \%$ & $\begin{array}{l}17.5 \% \\
(17 / 97)\end{array}$ & N/A & $\begin{array}{l}16.5 \% \\
(16 / 97)\end{array}$ & $\begin{array}{l}17.5 \% \\
(17 / 97)\end{array}$ & $\begin{array}{l}5.9 \% \\
(1 / 17)\end{array}$ & $\begin{array}{l}5.9 \% \\
(1 / 17)\end{array}$ \\
\hline $\begin{array}{l}\text { Peters } \\
\text { et al. [22] }\end{array}$ & $\begin{array}{l}\text { STI clinic, } \\
\text { The Hague, } \\
\text { Netherlands,'07-'08 }\end{array}$ & Had RAl & 850 & $\begin{array}{l}8.8 \% \\
(75 / 850)\end{array}$ & 100 \% @6 & $0 \%$ & $\begin{array}{l}8.8 \% \\
(75 / 850)\end{array}$ & N/A & $\begin{array}{l}8.9 \% \\
(76 / 850)\end{array}$ & $\begin{array}{l}10.8 \% \\
(92 / 850)\end{array}$ & $\begin{array}{l}20.7 \% \\
(16 / 92)\end{array}$ & $\begin{array}{l}21.3 \% \\
(16 / 75)\end{array}$ \\
\hline $\begin{array}{l}\text { Javanbakt } \\
\text { et al. [17] }\end{array}$ & $\begin{array}{l}\text { STI clinics USA } \\
\text { '08-'10 }\end{array}$ & Had RAl & 1203 & $\begin{array}{l}14.6 \% \\
(171 / 1203)\end{array}$ & 100 \% @3 & $0 \%$ & $\begin{array}{l}14.6 \% \\
(171 / 1203)\end{array}$ & N/A & $\begin{array}{l}12.0 \% \\
(144 / 1203)\end{array}$ & $\begin{array}{l}16.0 \% \\
(193 / 1203)\end{array}$ & $\begin{array}{l}25.4 \% \\
(49 / 193)\end{array}$ & $\begin{array}{l}28.7 \% \\
(49 / 171)\end{array}$ \\
\hline $\begin{array}{l}\text { Shaw } \\
\text { et al. [23] }\end{array}$ & STI clinic UK, before ' 13 & Had RAl & 312 & $\begin{array}{l}7.1 \% \\
(22 / 312)\end{array}$ & 100 \% @u & $0 \%$ & $\begin{array}{l}7.1 \% \\
(22 / 312)\end{array}$ & N/A & $\begin{array}{l}6.7 \% \\
(194 / 3043)\end{array}$ & N/A & N/A & $\begin{array}{l}22.7 \% \\
(5 / 22)\end{array}$ \\
\hline
\end{tabular}


Table 2 Overview of studies that include anorectal Chlamydia trachomatis (CT) nucleic acid amplification testing in women by routine systematic testing or selective testing on indication of receptive anal sex (RAl) or otherwise (Continued)

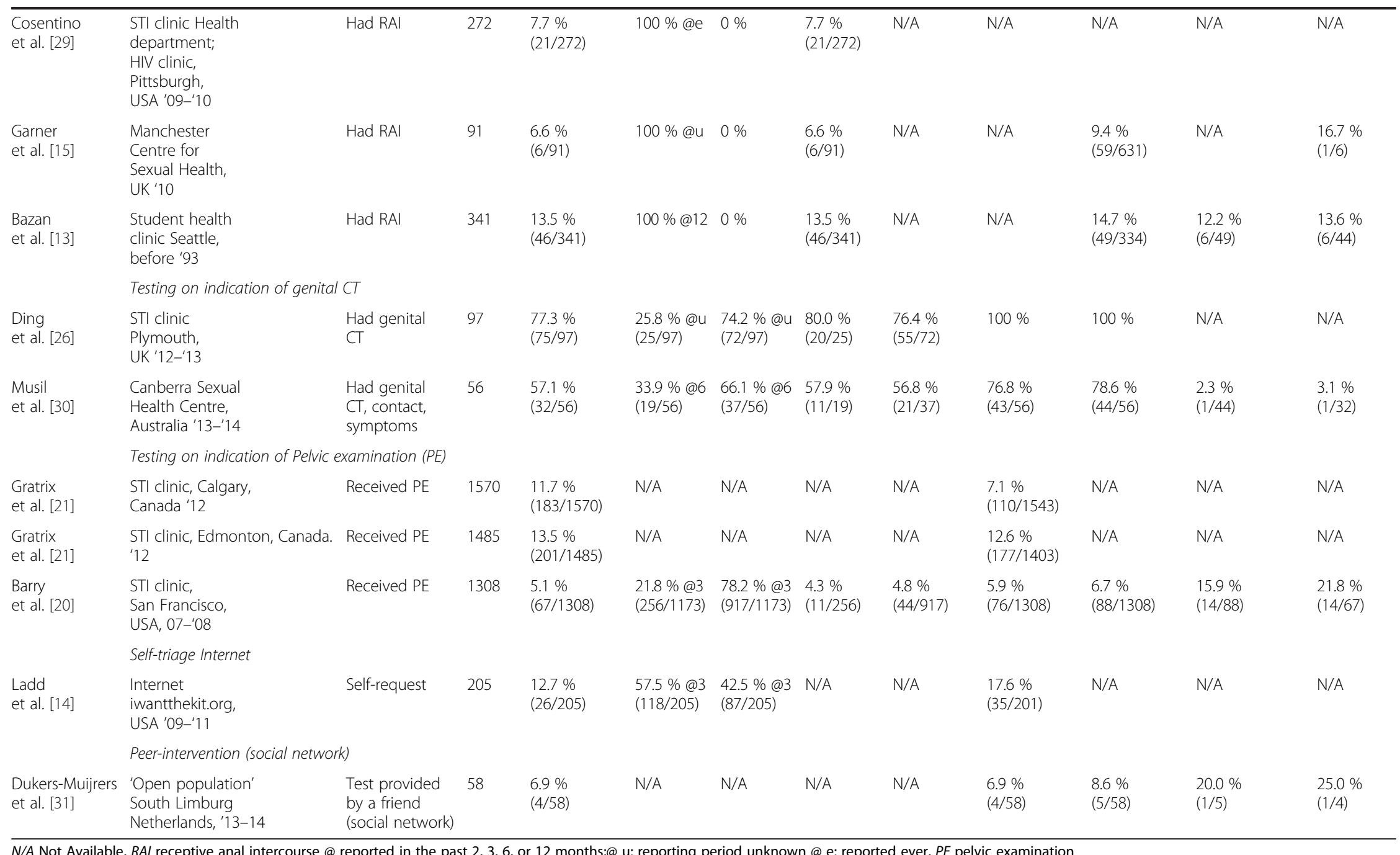

Not Available, RAl receptive anal intercourse @ reported in the past 2, 3, 6, or 12 months;@ u: reporting period unknown @ e: reported ever, PE pelvic examination 
prevalences up to $3 \%$, while prevalences in MSM are up to $21 \%[10-18,20-25,28,29,33,34,36-39]$.

\section{Concurrence of infections at extra-genital and genital sites}

There are notable differences between women and MSM in how frequent an infection at the extra-genital site occurs together with infection at the genital site. A women with an anorectal infection usually also has a concurrent genital infection. The studies presented in Table 2 show that in women, between 5 and $29 \%$ of the anorectal CT infections are single site anorectal infections, i.e. without a genital infection.

Among the women who have a CT or NG infection at the genital site (which is routinely tested for in care), a substantial part have a concurrent infection at the anorectal site: between $33 \%$ (i.e. [12]) and $83 \%$ (i.e. [11]) of women with genital $\mathrm{CT}$ also were found to have an anorectal CT (calculated from the studies presented in Table 2).

In contrast, MSM with anorectal infections usually do not have a concurrent infection at the genital site. In MSM anorectal infections are mostly single site infections, i.e. up to $91 \%$ for CT and up to $70 \%$ for NG [33-39, 43]. Still, similar to women who have a genital infection, a large proportion of MSM who have a genital infection may have a concurrent infection at the anorectal site: one study of 2436 MSM in a Dutch STI clinic found anorectal infections in about half of genitally infected MSM [43].

Pharyngeal CT prevalence is low in MSM and in women (see Table 1), and in both sexes frequently occurs in the absence of anorectal or genital CT, e.g. of pharyngeal CT $32-44 \%$ was single in women and 53$85 \%$ in MSM [18, 32, 33, 43-47]. Pharyngeal NG prevalence is higher in MSM than in women (see Table 1), and also frequently occurs as a single infection in both sexes. For example one study revealed $53 \%$ of pharyngeal NG infections were single in MSM and $73 \%$ in women [43].

\section{Current management Testing practices}

Detection of extra-genital CT and NG is best done by NAAT [7]. Such tests are highly sensitive and specific and were shown valid and robust for extra-genital detection (e.g. [25, 29, 48, 49]). Also, self-collection of samples in case of anorectal infections is well accepted and feasible in both women and in men. Still, the lack of clearance from the Food and Drug Administration (FDA-USA regulations) and lack of a CE-IVD mark (European regulations) for such testing, has greatly hampered its use in current clinical practice [50].

The focus in current health care is not on extra-genital testing; it has largely remained on genital testing. For example, a laboratory surveillance from all types of health care providers who perform CT testing in Australia showed that only in $3 \%$ of the test episodes was extragenital CT tested alongside genital CT [51]. This is further corroborated by a study from The Netherlands showing that GPs and gynecologists performed more CT tests than did STI clinics, but they infrequently $(<1 \%)$ tested for anorectal or pharyngeal CT [52]. Extra-genital testing, when it is done, is done in the STI clinic setting, and CT and NG are usually tested simultaneously because most commercially available NAATs detect both. However, such extra-genital testing tends to focus on MSM, not women, and test practices vary widely between STI clinics, even within a country $[18,34,53]$.

\section{Testing guidelines}

Current international guidelines for CT and NG testing [5-9] include a pharyngeal or anorectal test after symptoms and after behavioral exposure, i.e. receptive oral sex or receptive anal sex, respectively. Most guidelines focus on MSM and some also include specific groups of women, such as sex workers. None of the guidelines include women in general as a target group. Unfortunately, the recommendation to restrict testing to certain exposure risks has not been based on evidence. Actual testing results show that extragenital testing of all people reporting extra-genital exposure would still result in over half of extra-genital infections remaining undetected in both women (see Table 2) and in MSM who attend health care for genital testing $[11,18,24,25,32-39,43-47]$. The prevalence of anorectal CT was consistently similar between women reporting and not reporting (receptive) anal sex, as shown in Table 2. Similar observations have been made for NG, and also in MSM. Could the observed presence of anorectal infections be explained by underreporting of anal sexual exposure? Reporting bias is unlikely to explain a major part as then such bias would need to be unrealistically high and consistent across studies and countries. Bias by using a recall period that is too short to capture the behavioral exposure is probably more likely, given that anal sex is usually recorded as behavior in a given time period (usually a couple of months). Oral and anal sex are commonly reported by women and MSM [10, 11, 20, 26, 27, 54]. Therefore, infections may have been acquired before the beginning of the screening interval, and be unnoticed due to its asymptomatic nature and lack of extra-genital testing. It has been suggested that anorectal pathogens may potentially be transmitted by practices that involve contact with the anus other than penetrative analgenital sex (i.e. by transmission by fingers or by sex toys), although evidence for this is inconclusive $[10,30,55]$. 
It should be noted that for anorectal infections, transmission methods other than sex with by an infected partner have been postulated. The most plausible of these in women is self-infection (autoinoculation). The presence of anorectal infections in women without anal sex and the high rate of concurrence with infections at the genital site, fuelled the belief that anorectal infections in women are largely the result of self-infection. The anatomical proximity of genital and anorectal site makes this plausible. However, self-infection has not been confirmed by rigorous data. Also, the observed high rates of concurring genital and anorectal infections in women is predictable given the likelihood that women who have anal sex will also have vaginal sex [54]. Possibly differences in behavior between the women and MSM (frequency of anal sex, number of anal sex partners, co-practice of anal and genital intercourse) may also drive discordance of anatomic site infections. Further, it can be considered very unlikely that possible swab contamination by inadequate swab handling (due to contamination from the genital infection or the environment), would contribute much to the observed anorectal detections $[25,56]$. A different theory to explain anorectal CT detection involves the gastrointestinal (GI) tract as a reservoir for CT detection. While asymptomatic CT infections have been detected in the GI tract of neonates exposed at birth, and rectal shedding has been observed in children in trachoma endemic areas, the theory that the GI tract could act as a reservoir in humans, for example though oral exposure, was more recently shaped by new observations in mice [57-59]. However, evidence to support long term persistence of CT in the GI tract in human adults is completely lacking.

The vast majority of extra-genital CT and NG are asymptomatic, i.e. without oral or anorectal symptoms reported [1,2]. Even in the case for LGV, many infections in MSM have been shown to go without symptoms [40, 41]. In fact, this is similar to genital infections, that are also frequently asymptomatic. There is little or no evidence that CT strains differ between anatomic sites regarding their genotype or their pathogenic potential. In MSM, some studies demonstrated associations between anorectal NG infections, anorectal NG bacterial load and proctitis $[35,47,60]$. Still, it should be noted that generally anorectal symptoms are rarely reported $(<5 \%)$ and that most extra-genital infections are without symptoms.

\section{Treatment}

Generally, treatments recommended for extra-genital STI do not differ from that of genital STI. For CT however, the recommended first choice treatments may differ between anorectal and genital infection. For genital
CT infection azithromycin 1-g single dose is advised. For anorectal CT, azithromycin or doxycycline 100mg twice daily for seven days are considered equal first line treatments in the US. Other countries (Netherlands, Australia, and UK in their most recent draft of guidelines) now have doxycycline as first choice in anorectal CT [5-9]. These new recommendations reflect concern that azithromycin efficacy for anorectal infections may be less than what was expected. Yet, neither recommendation, i.e. to use the treatments as equal first line treatments or prefer the one over the other, stems from robust studies showing equivalent or different efficacy at different anatomic sites. These recommendations are extrapolated from solid evidence supporting the efficacy of these regimens for genital CT treatment and from clinical experience and expert consultation [61-63]. The internationally recommended treatment regimen for LGV is a 3-week course of oral doxycycline $100 \mathrm{mg}$ twice daily [55]. Genital and extra-genital NG can be treated with ceftriaxone or with ciprofloxacin when ceftriaxone is contraindicated and strains show no ciprofloxacin resistance [5-9].

\section{Discussion}

Routine extra-genital testing for CT and NG is possible using NAAT and minimally invasive sampling methods. However, extra-genital infections are still not routinely tested for in MSM and testing is even less common in women. As these infections are mostly asymptomatic, they are frequently overlooked in health care. Extra-genital infections, in women especially anorectal $\mathrm{CT}$, are common and testing based on exposure or symptoms misses over half of these extra-genital infections. More testing in women and in MSM would identify many more extra-genital infections. But, what are the implications for clinical practice of testing more? Untreated infections might continue to cause complications and potentially drive further transmission. Still, what are the public health gains of testing more? Should control strategies be different for MSM and women? Some answers to these questions will provide us with more insight into what is needed to guide extra-genital testing in MSM and in women.

\section{What are implications for clinical practice of managing extra-genital CT and NG?}

Testing more patients and testing more samples per patient A substantial proportion of infected individuals do not attend a testing facility for testing or retesting, and are obviously missed, hence remain untreated [64]. Even so, when people do attend care, they are in most cases tested at genital sites only. Addressing currently hidden CT and NG by extra-genital testing 
of more persons would reveal many more extragenital infections. Several approaches to increase testing coverage for genital and anorectal infections have been evaluated and found feasible. These include using self-collected samples at home, and using automated e-health programs $[14,31,65,66]$.

Of patients who have an anorectal infection, women frequently have a concurrent infection at the genital site while MSM frequently do not have a concurrent genital infection. This implies that adding a extra-genital test to routine genital testing would reveal much more additional infected individual MSM than it would for women, even when the prevalence is similar (such as in anorectal CT). This also implies that to detect large part of extra-genital infections in women we could just test women with genital infections. A strategy to achieve this, without having to ask the women to come back for extra-genital testing, could be to directly take a extragenital sample at the routine genital STI testing visit, but to only test the extra-genital specimen from women who tested positive for their genital infection. In such case, fewer extra-genital laboratory tests would have to be performed compared to routine testing of both specimens in women, perhaps reducing costs. Yet, such phased testing strategy would also demand more complex laboratory logistics and increase time to return test results. Using this strategy implies there is a reason to detect the extra-genital infection in a women who will be treated because of her genital infection (different treatment regimen or different partner management needed?). Also, such phased testing strategy would not detect the single site extra-genital infections that still will remain undiagnosed and untreated. Another testing strategy potentially reducing costs is to test pooled multiple site samples. Such approach precludes feedback on the anatomic site(s) where the infection(s) occurs precluding treatment guidance, and its effectiveness needs to be further explored.

More information on the clinical and public health impact is needed to decide what would be the optimal cost-effective algorithm for testing. This clinical and public health impact of leaving extra-genital infections untested may be different between the two sexes. This is because the co-occurrence of infections at multiple anatomic sites differs between MSM and women and may impact the need for additional management strategies. The clinical and public health impact also is dependent on the (yet unknown) role of extra-genital infections in morbidity and transmission.

Further insight on these issues is essential to know how the additional costs of testing extra-genital samples and managing more identified positive cases balances the costs avoided by reducing spread and morbidity due to extra-genital testing.

\section{Making different treatment choices}

If treatment for genital infections is also adequate for extra-genital infections, then part of the extra-genital CT and NG would be 'inadvertently treated' by treating the infection at the genital site (that is usually routinely screened). This would most frequently apply to anorectal infections in women, as these usually co-occur with a genital infection, reducing the negative consequences (in terms of morbidity and transmission) of leaving anorectal CT and NG infections in women untested. However, this scenario may not be true for anorectal CT. There are reports suggesting that doxycycline is a better treatment for anorectal CT than is azithromycin [61-63]. If a clinician knew the patient also had an anorectal CT, a different treatment choice might be made. At the moment, we lack thorough studies to decide what is the best treatment for anorectal CT. Restrictions in financial means for extra-genital testing has led some clinicians to taking a pragmatic approach by directly treating genital $\mathrm{CT}$ positive patients with doxycycline, assuming this will treat a potential concurrent anorectal infection better than when using azithromycin. Still, the strategy to use doxycycline in anorectal CT is not based on solid evidence. Such strategy is also limited by the higher noncompliance rates seen with doxycycline use because of its longer treatment duration [67]. Until we better understand the effectiveness of anorectal CT treatment regimens, the impact of not testing for anorectal $\mathrm{CT}$ in women is difficult to assess. Well designed randomized controlled trials on this topic are urgently needed.

In MSM, an additional contributing factor to increasing the adverse consequences of an untested extragenital CT, is the occurrence of LGV. LGV prevalence is low, and there are marked differences in geographic distribution, but it requires additional and different testing and treatment.

\section{Managing so far undetected treatment resistance}

The introduction of NG treatment resistant strains poses a challenge for its management [68]. So far, there are no reports that its occurrence is different for genital or extra-genital NG, although it has been suggested that pharyngeal NG may act as a reservoir for resistance [69]. Not (appropriately) treating extra-genital NG may increase the spread of resistant NG in the population, especially in MSM who show a higher prevalence than women. Mathematical modeling suggested that the most effective control strategy for treatment resistant NG is by following up treated infections to re-treat failures, rather than just testing and treating more patients [70]. This could equally apply for extra-genital infections.

For CT, there is yet no evidence of homotypic antimicrobial resistance [71]. Still, our understanding is limited as testing for antimicrobial resistance for CT is not 
routinely available, although whole genome sequencing provides new opportunities [72].

\section{Making more customized patient and partner management choices}

Management strategies such as re-testing, partner notification and expedited or accelerated partner treatment have been shown to be highly effective strategies to prevent relatively high numbers of CT and NG [73]. Partners of positive patients and previously tested positive patients have a greater risk to also test positive. Treatment of the sexual partners of positive cases is therefore recommended (partner-notification) and infected patients themselves are advised to be re-tested between 3-12 months post-treatment to detect a new CT or NG infection [3-9]. While for CT, the usefulness of performing a test-of-cure can be seriously questioned [74, 75], for NG, a test-of-cure may sometimes be recommended to detect a persistent infection [3-9] and as recently suggested, to manage treatment resistant NG [70]. Again, extra-genital infections may in part be incidentally handled by the strategies deployed for a detected genital infection. However, it is not clear whether such incidental handling is effective for extra-genital infections. For example, partner notification may not be applied when the patient did have unprotected anal/oral sex but unprotected genital sex was not reported and a test-of-cure may be negative for a genital NG, while it may be positive for (untested) anorectal or pharyngeal NG.

It also is apparent that by not testing, a single extragenital infection would always be missed and none of the treatment, retest or partner notification strategies would be employed. Therefore, by testing and treating at genital sites only, essential control opportunities in the management of both female and MSM patients and their partners are lost.

\section{What are public health gains by managing extra-genital CT and NG? \\ Avoided morbidity}

Some studies in MSM linked anorectal NG to symptomatic proctitis, which is an inflammatory syndrome of the distal $10-12 \mathrm{~cm}$ of the rectum. Some LGV strains cause a severe proctocolitis [55]. In women, it is yet unknown whether anorectal infections can cause anal symptoms. Even so, the large majority of extra-genital (and genital) infections in MSM and in women are asymptomatic and no solid evidence is present showing that symptoms are regularly associated with anorectal CT or pharyngeal CT or NG infections.

Hypothetically, anorectal infections in women could have an impact on the reproductive outcomes. This would be if an anorectal infection could be spread to the genital site. A recent study estimated that, when selfinfection from the anorectal site plays a role, a less adequate treatment would sustain CT in a woman [76]. Thus anorectal infections would act as a reservoir (by self-infection, or during sexual activity) for genital infections (or re-infections). This would expand the spectrum of morbidity of anorectal infections in women, increasing the negative consequences of overlooking the anorectal infection. In genital $\mathrm{CT}$, repeat infections have been linked to increased reproductive morbidity - more PID and more adverse reproductive outcomes; it is unknown if morbidity is also linked to repeat infection with extra-genital STI.

\section{Avoided transmission}

Pharyngeal and anorectal CT and NG are probably capable of being transmitted to genital sites of a partner $[77,78]$. In women, infections may potentially be transmitted from their anorectal to genital site.

In the absence of better data on the transmission potential of extra-genital infections, any extra-genital STI that remains untreated should be considered transmissible. Given that there is a large number of extra-genital CT and NG currently missed by the current standard of care (i.e. untested, untreated or possibly sub-optimally treated), the transmission potential of such infections may be huge in women and in MSM. Infections at extra-genital sites may impact the total STI burden in the population by spread between sexual partners and even between a woman's anatomic sites. A recent mathematical study in MSM suggest that oral sex has an important role in sustaining NG in MSM by providing a pool of untreated asymptomatic infection [79]. If extragenital CT and NG infections in women and MSM do importantly help to sustain CT and NG endemicity, then the gaps in their current management could help explain why we do not see a decrease in CT and NG prevalence from surveillance data in the face of greatly increased genital testing and treating efforts [3, 4, 64].

Data on factors facilitating transmission are yet unavailable. It is for example unknown whether anorectal and pharyngeal bacterial load is associated with an increased risk for transmission, although such associations may be biologically plausible. The CT and NG load detected on pharyngeal or anorectal swabs load is generally lower than on genital swabs [32, 60, 75, 80-82]. Nevertheless, only few studies have yet directly compared bacterial loads between anatomic sites. It is unknown what are the transmission probabilities in relation to exposure, i.e. after exposure by an alternate anatomic site or after sex with an infected partner. A recent study among 51 women who reported anal sex and 90 MSM who reported anal sex found similar mean numbers and ranges in anorectal CT load [82]. This may suggest equal 
transmission probabilities in MSM and women reporting anal sex. Future mathematical models and prospective studies using multi-site sampling and measuring bacterial load, and culture to detect viable bacteria could help to obtain more insight in these aspects.

Missing extra-genital infections may also impact the transmission of other STI. In MSM, it has been shown that anorectal CT and NG facilitate HIV transmission [83-85]. Analyses even support the idea of a causal effect of incident anorectal STI on HIV diagnosis [86]. Given the high prevalences of anorectal CT and NG infections in MSM, it is not unreasonable to speculate that they may have played an important role in driving the HIV epidemic in these men. Therefore, anorectal CT and NG testing is a potentially cost-effective and scalable intervention to reduce $\mathrm{HIV}$ acquisition in high risk MSM [87, 88]. In populations with lower HIV prevalence, such as women in industrialized countries, such interventions may not be cost-effective. Yet, in women, an association between anorectal infections and HIV, whilst not yet studied, is plausible. This is because many studies have shown that the presence of genital STI is associated with increased HIV transmission in heterosexuals, and women have unprotected anal sex and anorectal STI, which are both acknowledged as important risk factors for HIV acquisition in MSM.

\section{Other extra-genital STI}

As we have started to gain awareness of the occurrence of extra-genital CT and NG in women, we have been learning about other extra-genital STI as well. We know that Mycoplasma genitalium (MG), Herpes Simplex Virus, Human Papilloma Virus (HPV) and Trichomonas vaginalis $(\mathrm{TV})$ can be found at the anorectal site in a woman. Presence at the anorectal site may be correlated to their presence in the vagina, such as has been shown for MG, TV and HPV [29, 89-91]. While some of these pathogens are routinely tested for at the genital sites of women, anorectal or pharyngeal testing of these STI is rarely done in practice. It is also not recommended and hampered when there are no available commercial assays (such as for MG). NAAT assays for the simultaneous detection of several anorectal infections 'in one' are being developed, and that perhaps may pose interesting future possibilities for combined extra-genital testing. The gaps that are revealed in the management of extragenital CT and NG may also apply for these other STI. Further, detecting the simultaneous presence of different extra-genital pathogens will impact patient-management.

\section{Summary and conclusion}

Extra-genital CT and NG, and perhaps other STI such as MG, may form a high potential for avoidable transmission and to some extent for avoidable morbidity in
MSM and in women. Extra-genital CT and NG can be successfully detected using NAAT on simple to obtain self-taken samples. Both men and women are willing to test, and the so far hidden extra-genital STI epidemic can be revealed. Strategies can be taken to increase the reach of the testing and reduce costs by using internet based programs, e-health strategies and home-collection. Still several of the tests (NAAT testing on extra-genitally taken samples) and strategies (home-collection) are not FDA cleared. It is likely that, at least in the US, the needed paradigm shift from a genital-centered approach to testing (MSM and others at risk) to include a broader sampling frame, will not become routine until FDA clearance for extra-genital testing is obtained.

Testing should not solely be guided by indication of symptoms or behavioral exposure as the large majority of extra-genital STI are asymptomatic and over half of the extra-genital infections occur in the absence of (report of) such symptoms or behavioural exposures in both women and MSM. The majority of extra-genital infections in MSM are single site infections that are not being 'inadvertently managed' by treating urethral infections. Based on the current available data routine universal testing of all MSM instead of only testing MSM who report symptoms or behavioural exposure is therefore an imperative. To date, there is no evidence that the public health impact, in terms of transmission, of anorectal or pharyngeal infections is any different for women than it is for MSM. However, in women, the clinical implications of extra-genital infections, and gains by testing these, present uncertainties. In women, whether or not to implement routine testing would depend on the increment achieved in terms of avoided morbidity and further spread. For some less prevalent STI, such as NG in some countries, the increment is likely smaller in women than MSM due to the more infrequent occurrence of these infections in women. For more prevalent STI, such as CT and perhaps MG, the increment would depend on the number extra-genital infections that could be adequately managed (by treatment and partner management) above the number of infections that are already adequately managed by standard care for the genital infection. We lack essential information in several key area's (summarized in Table 3) that need to be addressed to fully understand the scope of impact on public health and the clinical implications posed by the occurrence of extra-genital STI in women but also in MSM.

Future studies should address extra-genital and genital morbidity caused by extra-genital infections. Randomized controlled trials are needed to determine whether treatment efficacy for extra-genital infections differs from that of genital infections. The full spectrum including potential for further transmission of extra-genital 
Table 3 Key research area's in understanding the clinical and public health impact of extra-genital Chlamydia trachomatis (CT) and Neisseria gonorrhoeae (NG) infections in women and in men who have sex with men (MSM)

\begin{tabular}{|c|c|}
\hline Key research area & Knowledge Gap on extra-genital CT and NG infections in women and MSM \\
\hline \multirow[t]{2}{*}{ Morbidity } & Proctitis in anorectal infections \\
\hline & Reproductive morbidity (women) \\
\hline $\begin{array}{l}\text { Efficacy control strategies: } \\
\text { Treatment }\end{array}$ & $\begin{array}{l}\text { Efficacy of treatment for both extra-genital and genital infections and associated factors (including treatment resist- } \\
\text { ance, tissue absorption, duration of treatment to account for } C T \text { life cycle phases) }\end{array}$ \\
\hline $\begin{array}{l}\text { Efficacy control strategies: } \\
\text { Re-testing, partner management }\end{array}$ & $\begin{array}{l}\text { Efficacy of strategies to manage extra-genital infections (including strategies that are already taken to manage geni- } \\
\text { tal infections) }\end{array}$ \\
\hline \multirow[t]{3}{*}{ Transmission } & Transmission risk between sexual partners and associated factors, such as bacterial load, sexual behavior \\
\hline & $\begin{array}{l}\text { Self-infection, i.e. transmission risk between anatomic sites within a patient and associated factors, i.e. bacterial load, } \\
\text { sexual behavior (women) }\end{array}$ \\
\hline & Role in the transmission of other STI including HIV \\
\hline Detection & $\begin{array}{l}\text { Microbiologic specifics of a CT - NAAT detection such as bacterial load, viability or other possible markers of } \\
\text { transmission or of morbidity }\end{array}$ \\
\hline Testing policy & $\begin{array}{l}\text { Cost effectiveness of extra-genital } C T \text { and NG testing taking into account the key research area's of efficacy of } \\
\text { extra-genital control-strategies, transmission and morbidity }\end{array}$ \\
\hline
\end{tabular}

infections to genital sites and related morbidity has not yet been evaluated in women. Prospective studies in couples or modeling studies could reveal more insight on what are the transmission probabilities between partners and between anatomic sites, and the associated factors. Morbidity and transmission may depend on the extent the bacteria is able to replicate or presents in high loads, which is unknown in MSM and in women. Studies using appropriate laboratory techniques, such as quantitative PCR for measuring bacterial load, and culture to detect viable bacteria and antibiotic resistance, to address these aspects are needed. These will greatly aid our understanding of extra-genital infections and the differences presented by these infections in MSM and women. Finally, cost-effectiveness of extra-genital testing has been evaluated for HIV infected MSM and was shown cost-effective in case of anorectal CT and NG $[87,88]$. While it has been suggested that the lower prevalence of NG in women overall makes it more costly to screen for both CT and NG in women compared to MSM [15], this is in practice not likely a valid argument as most NAATs for CT are duplex assays also measuring NG with the same costs.

Hidden extra-genital infections might fuel the transmission of CT and NG and other STI and thereby increase the overall STI burden. This may be very important in the context of HIV and anorectal infection. Health care providers should be aware of the common occurrence of extra-genital infections. They should be doing more and urgently need a better understanding, especially in women, to obtain the highest gains of the increased CT and NG testing and treating efforts. Increased testing is an imperative for MSM. There is much to be learned to see if the same is true for women, and possibly for some heterosexual men as well.

\section{Ethics statement}

Ethical approval was not required for this paper as it is a debate paper and not original research involving humans.

\section{Abbreviations \\ CDC: Centers for Disease Control and Prevention; CT: Chlamydia trachomatis; FDA: Food and Drug Administration; HPV: Human Papilloma Virus; NAAT: Nucleic Acid Amplification Test; NG: Neisseria gonorrhoeae; MG: Mycoplasma genitalium; MSM: Men who have sex with men; TV: Trichomonas vaginalis.}

\section{Competing interests}

All authors report that they have no conflict of interest.

\section{Authors' contributions}

ND and JS conceptualized and designed the study and drafted the initial manuscript. ND, JS, GL, PW and CH contributed to the final manuscript and approved the final manuscript as submitted.

\section{Authors' information}

$N D$ and $G L$ are infectious diseases epidemiologists. JS is professor of Laboratory Medicine. CH is professor Infectious Disease Control and PW is a medical molecular microbiologist.

\section{Financial disclosure statement}

All authors report that they have no financial relationships that could be broadly relevant to the work.

\section{Author details}

${ }^{1}$ Department of Sexual Health, Infectious Diseases and Environmental Health, South Limburg Public Health Service, Geleenbeeklaan 2, 6166 GR Sittard-Geleen, The Netherlands. ${ }^{2}$ Department of Medical Microbiology, School of Public Health and Primary Care (CAPHRI), Maastricht University Medical Centre (MUMC+), Maastricht, The Netherlands. ${ }^{3}$ Department of Laboratory Medicine, University of California, San Francisco, CA, USA.

Received: 15 June 2015 Accepted: 12 November 2015 Published online: 17 November 2015

\section{References}

1. Price MJ, Ades AE, De Angelis D, Welton NJ, Macleod J, Soldan K, et al. Risk of pelvic inflammatory disease following Chlamydia trachomatis infection: analysis of prospective studies with a multistate model. Am J Epidemiol. 2013;178(3):484-92. doi:10.1093/aje/kws583. Epub 2013 Jun 27. 
2. Mitchell C, Prabhu M. Pelvic inflammatory disease: current concepts in pathogenesis, diagnosis and treatment. Infect Dis Clin North Am. 2013;27(4): 793-809. doi:10.1016/j.idc.2013.08.004. Epub 2013 Oct 31.

3. Centers for Disease Control and Prevention. 2013 Sexually Transmitted Diseases Surveillance: http://www.cdc.gov/std/stats13/chlamydia.htm (last accessed 8 June 2015)

4. European Centre for Disease Prevention and Control. Chlamydia control in Europe: literature review. Stockholm: ECDC; 2014

5. Sexually transmitted diseases treatment guidelines, 2015, Workowski KA, Bolan GA. Centers for Disease Control and Prevention (CDC). MMWR Recomm Rep. 2015;64(RR3):1-137.

6. British Association for Sexual Health and HIV (BASHH) (2010) Chlamydia trachomatis UK Testing Guidelines. Clinical Effectiveness Group. 2010 Update to Chlamydia testing. Available: http://www.bashh.org/documents/ 3352.pdf and http://www.bashh.org/guidelines (Last accessed 2015 June 01) and 2014 Draft UK national guideline for the management of genital infection with Chlamydia trachomatis

7. Centers for Disease Control and Prevention. Recommendations for the laboratory-based detection of Chlamydia trachomatis and Neisseria gonorrhoeae-2014. MMWR Recomm Rep. 2014;63(RR-02):1-19.

8. Australian STI management guidelines for use in primary care. http://www sti.guidelines.org.au/sexually-transmissible-infections/chlamydia\#diagnosis (Last accessed 2015 June 01.)

9. de Vries HJC, van Doornum GJJ, Bax CJ. Multidisciplinaire Richtlijn Seksueel Overdraagbare Aandoeningen voor de 2e Lijn, Nederlandse Vereniging voor Dermatologie en Venereologie. 2012. p. 1-151.

10. van Liere GA, Hoebe CJ, Wolffs PF, Dukers-Muijrers NH. High co-occurrence of anorectal chlamydia with urogenital chlamydia in women visiting an STI clinic revealed by routine universal testing in an observational study; a recommendation towards a better anorectal chlamydia control in women. BMC Infect Dis. 2014;14:274. doi:10.1186/1471-2334-14-274.

11. van Liere GA, Hoebe CJ, Niekamp AM, Koedijk FD, Dukers-Muijrers NH. Standard symptom- and sexual history-based testing misses anorectal Chlamydia trachomatis and neisseria gonorrhoeae infections in swingers and men who have sex with men. Sex Transm Dis. 2013;40(4):285-9. doi:10. 1097/OLQ.0b013e31828098f8.

12. Peters RP, Dubbink JH, van der Eem L, Verweij SP, Bos ML, Ouburg S, et al. Cross-sectional study of genital, rectal, and pharyngeal Chlamydia and gonorrhea in women in rural South Africa. Sex Transm Dis. 2014;41(9):564-9. doi:10.1097/OLQ.0000000000000175.

13. Bazan JA, Carr Reese P, Esber A, Lahey S, Ervin M, Davis JA, et al. High prevalence of rectal gonorrhea and Chlamydia infection in women attending a sexually transmitted disease clinic. J Womens Health (Larchmt). 2015;24(3):182-9. doi:10.1089/jwh.2014.4948. Epub 2015 Feb 18.

14. Ladd J, Hsieh YH, Barnes M, Quinn N, Jett-Goheen M, Gaydos CA. Female users of internet-based screening for rectal STIs: descriptive statistics and correlates of positivity. Sex Transm Infect. 2014;90(6):485-90. doi:10.1136/ sextrans-2013-051167. Epub 2014 Mar 6.

15. Garner AL, Schembri G, Cullen T, Lee V. Should we screen heterosexuals for extra-genital chlamydial and gonococcal infections? Int J STD Aids. 2014.

16. Hunte T, Alcaide M, Castro J. Rectal infections with chlamydia and gonorrhoea in women attending a multiethnic sexually transmitted diseases urban clinic. Int J STD AIDS. 2010;21(12):819-22. doi:10.1258/ijsa.2010. 009279

17. Javanbakht M, Gorbach P, Stirland A, Chien M, Kerndt P, Guerry S. Prevalence and correlates of rectal Chlamydia and gonorrhea among female clients at sexually transmitted disease clinics. Sex Transm Dis. 2012; 39(12):917-22. doi:10.1097/OLQ.0b013e31826ae9a2.

18. Koedijk FD, van Bergen JE, Dukers-Muijrers NH, van Leeuwen AP, Hoebe CJ, van der Sande MA, et al. The value of testing multiple anatomic sites for gonorrhoea and chlamydia in sexually transmitted infection centres in the Netherlands, 2006-2010. Int J STD AIDS. 2012;23(9):626-31. doi:10.1258/ijsa. 2012.011378.

19. Sethupathi M, Blackwell A, Davies H. Rectal Chlamydia trachomatis infection in women. Is it overlooked? Int J STD AIDS. 2010;21(2):93-5. doi:10.1258/ijsa. 2008.008406.

20. Barry PM, Kent CK, Philip SS, Klausner JD. Results of a program to test women for rectal chlamydia and gonorrhea. Obstet Gynecol. 2010;115(4): 753-9.

21. Gratrix J, Singh AE, Bergman J, Egan C, Plitt SS, McGinnis J, et al. Evidence for increased Chlamydia case finding after the introduction of rectal screening among women attending 2 Canadian sexually transmitted infection clinics. Clin Infect Dis. 2015;60(3):398-404. doi:10.1093/cid/ciu831.

22. Peters RP, Nijsten N, Mutsaers J, Jansen CL, Morré SA, van Leeuwen AP. Screening of oropharynx and anorectum increases prevalence of Chlamydia trachomatis and Neisseria gonorrhoeae infection in female STD clinic visitors. Sex Transm Dis. 2011;38(9):783-7. doi:10.1097/OLQ. Ob013e31821890e9.

23. Shaw SG, Hassan-Ibrahim M, Soni S. Are we missing pharyngeal and rectal infections in women by not testing those who report oral and anal sex? Sex Transm Infect. 2013;89(5):397. doi:10.1136/sextrans-2013-051159.

24. Bachmann LH, Johnson RE, Cheng H, Markowitz L, Papp JR, Palella Jr FJ, et al. Nucleic acid amplification tests for diagnosis of Neisseria gonorrhoeae and Chlamydia trachomatis rectal infections. J Clin Microbiol. 2010;48(5): 1827-32. doi:10.1128/JCM.02398-09. Epub 2010 Mar 24.

25. van der Helm JJ, Hoebe CJ, van Rooijen MS, Brouwers EE, Fennema HS, Thiesbrummel HF, et al. High performance and acceptability of selfcollected rectal swabs for diagnosis of Chlamydia trachomatis and Neisseria gonorrhoeae in men who have sex with men and women. Sex Transm Dis. 2009:36(8):493-7. doi:10.1097/OLQ.0b013e3181a44b8c.

26. Ding A, Challenor R. Rectal Chlamydia in heterosexual women: more questions than answers. Int J STD AIDS. 2013;25(8):587-92 [Epub ahead of print].

27. Ostergaard L, Agner T, Krarup E, Johansen UB, Weismann K, Gutschik E. PCR for detection of Chlamydia trachomatis in endocervical, urethral, rectal, and pharyngeal swab samples obtained from patients attending an STD clinic. Genitourin Med. 1997;73(6):493-7.

28. Trebach JD, Chaulk CP, Page KR, Tuddenham S, Ghanem KG. Neisseria gonorrhoeae and Chlamydia trachomatis Among Women Reporting Extra-genital Exposures. Sex Transm Dis. 2015;42(5):233-9. doi:10.1097/ OLQ.0000000000000248.

29. Cosentino LA, Campbell T, Jett A, Macio I, Zamborsky T, Cranston RD, et al. Use of Nucleic Acid Amplification Testing for Diagnosis of Anorectal Sexually Transmitted Infections. J Clin Microbiol. 2012;50(6):2005-8. doi:10. 1128/JCM.00185-12 PMCID: PMC3372150.

30. Musil K, Currie M, Sherley M, Martin S. Rectal chlamydia infection in women at high risk of chlamydia attending Canberra Sexual Health Centre. Int J STD Aids. 2015

31. Dukers-Muijrers NH, Theunissen KA, Wolffs PT, Kok G, Hoebe CJ. Acceptance of Home-Based Chlamydia Genital and Anorectal Testing Using Short Message Service (SMS) in Previously Tested Young People and Their Social and Sexual Networks. PLOS ONE. 2015;10(7):e0133575. doi:10.1371/journal. pone.0133575. eCollection 2015

32. van Rooijen MS, Schim van der Loeff MF, Morré SA, van Dam AP, Speksnijder AG, de Vries HJ. Spontaneous pharyngeal Chlamydia trachomatis RNA clearance. A cross-sectional study followed by a cohort study of untreated STI clinic patients in Amsterdam, The Netherlands. Sex Transm Infect. 2014. doi: 10.1136/sextrans-2014-051633. [Epub ahead of print]

33. Kent CK, Chaw JK, Wong W, Liska S, Gibson S, Hubbard G, et al. Prevalence of rectal, urethral, and pharyngeal chlamydia and gonorrhea detected in 2 clinical settings among men who have sex with men: San Francisco, California, 2003. Clin Infect Dis. 2005;41(1):67-74. Epub 2005 May 26.

34. Patton ME, Kidd S, Llata E, Stenger M, Braxton J, Asbel L, et al. Extra-genital gonorrhea and chlamydia testing and infection among men who have sex with men-STD Surveillance Network, United States, 2010-2012. Clin Infect Dis. 2014;58(11):1564-70. doi:10.1093/cid/ciu184. Epub 2014 Mar 18.

35. Ivens D, Macdonald K, Bansi L, Nori A. Screening for rectal chlamydia infection in a genitourinary medicine clinic. Int J STD AIDS. 2007;18(6):404-6.

36. Dudareva-Vizule S, Haar K, Sailer A, Wisplinghoff H, Wisplinghoff F, Marcus U, et al. Prevalence of pharyngeal and rectal Chlamydia trachomatis and Neisseria gonorrhoeae infections among men who have sex with men in Germany. Sex Transm Infect. 2014:90(1):46-51. doi:10.1136/sextrans-2012050929. Epub 2013 Aug 6.

37. Chow EP, Tomnay J, Fehler G, Whiley D, Read TR, Denham I, et al. Substantial increases in chlamydia and gonorrhea positivity unexplained by changes in individual-level sexual behaviors among men who have sex with men in an Australian sexual health service from 2007 to 2013. Sex Transm Dis. 2015;42(2):81-7. doi:10.1097/OLQ. 0000000000000232

38. Marcus U, Ort J, Grenz M, Eckstein K, Wirtz K, Wille A. Risk factors for HIV and STI diagnosis in a community-based HIV/STI testing and counselling site for 
men having sex with men (MSM) in a large German city in 2011-2012. BMC Infect Dis. 2015;15(1):14 [Epub ahead of print].

39. Park J, Marcus JL, Pandori M, Snell A, Philip SS, Bernstein KT. Sentinel surveillance for pharyngeal chlamydia and gonorrhea among men who have sex with men-San Francisco, 2010. Sex Transm Dis. 2012;39(6):482-4 doi:10.1097/OLQ.0b013e3182495e2f.

40. Haar K, Dudareva-Vizule S, Wisplinghoff H, Wisplinghoff F, Sailer A, Jansen K, et al. Lymphogranuloma venereum in men screened for pharyngeal and rectal infection, Germany. Emerg Infect Dis. 2013;19(3):488-92. doi:10.3201/ eid1903.121028.

41. de Vrieze NH, van Rooijen M, Speksnijder AG, de Vries HJ. Urethral lymphogranuloma venereum infections in men with anorectal lymphogranuloma venereum and their partners: the missing link in the current epidemic? Sex Transm Dis. 2013;40(8):607-8. doi:10.1097/01.OLQ 0000431359.26583 .13$.

42. Verweij SP, Ouburg S, de Vries H, Morré SA, van Ginkel CJ, Bos H, et al. The first case record of a female patient with bubonic lymphogranuloma venereum (LGV), serovariant L2b. Sex Transm Infect. 2012;88(5):346-7. doi:10. 1136/sextrans-2011-050298.

43. van Liere GA, Hoebe CJ, Dukers-Muijrers NH. Evaluation of the anatomical site distribution of chlamydia and gonorrhoea in men who have sex with men and in high-risk women by routine testing: cross-sectional study revealing missed opportunities for treatment strategies. Sex Transm Infect. 2014;90(1):58-60. doi:10.1136/sextrans-2013-051248. Epub 2013 Oct 8.

44. Templeton DJ, Jin F, McNally LP, Imrie JC, Prestage GP, Donovan B, et al. Prevalence, incidence and risk factors for pharyngeal gonorrhoea in a community-based HIV-negative cohort of homosexual men in Sydney, Australia. Sex Transm Infect. 2010;86(2):90-6. doi:10.1136/sti.2009.036814. Epub 2009 Oct 19

45. Ota KV, Fisman DN, Tamari IE, Smieja M, Ng LK, Jones KE, et al. Incidence and treatment outcomes of pharyngeal Neisseria gonorrhoeae and Chlamydia trachomatis infections in men who have sex with men: a 13-year retrospective cohort study. Clin Infect Dis. 2009;48(9):1237-43. doi:10.1086/ 597586

46. Tipple C, Hill SC, Smith A. Is screening for pharyngeal Chlamydia trachomatis warranted in high-risk groups? Int J STD AIDS. 2010;21(11): 770-1. doi:10.1258/ijsa.2010.009494.

47. Manavi K, Zafar F, Shahid H. Oropharyngeal gonorrhoea: rate of co-infection with sexually transmitted infection, antibiotic susceptibility and treatment outcome. Int J STD AIDS. 2010;21(2):138-40. doi:10.1258/ijsa.2009.009167. Epub 2009 Nov 2.

48. Schachter J, Moncada J, Liska S, Shayevich C, Klausner JD. Nucleic acid amplification tests in the diagnosis of chlamydial and gonococcal infections of the oropharynx and rectum in men who have sex with men. Sex Transm Dis. 2008;35(7):637-42. doi:10.1097/OLQ.0b013e31817bdd7e.

49. Moncada J, Schachter J, Liska S, Shayevich C, Klausner JD. Evaluation of selfcollected glans and rectal swabs from men who have sex with men for detection of Chlamydia trachomatis and Neisseria gonorrhoeae by use of nucleic acid amplification tests. J Clin Microbiol. 2009;47(6):1657-62. doi:10. 1128/JCM.02269-08. Epub 2009 Apr 15.

50. Schachter J, Philip SS. Testing men who have sex with men for urethral infection with Chlamydia trachomatis and Neisseria gonorrhoeae is only half the job, and we need the right tools. Sex Transm Dis. 2011;38(10): 925-7. doi:10.1097/OLQ.0b013e318230f3d6.

51. Dimech W, Lim MS, Van Gemert C, Guy R, Boyle D, ACCESS collaboration, et al. Analysis of laboratory testing results collected in an enhanced chlamydia surveillance system in Australia, 2008-2010. BMC Infect Dis. 2014;14:325. doi: 10.1186/1471-2334-14-325.

52. den Heijer CD, van Liere GA, Hoebe CJ, van Bergen JE, Cals JW, Stals FS et al. NH. Who tests whom? A comprehensive overview of Chlamydia trachomatis test practices in a Dutch region among different STI care providers for urogenital, anorectal and oropharyngeal sites in young people: a cross-sectional study. Sex Transm Infect. 2015. doi: 10. 1136/sextrans-2015-052065.

53. McMillan A, Kell P, Ward H. British Co-operative Clinical Group of British Association for Sexual Health and HIV Diagnosing chlamydia and managing proctitis in men who have sex with men: current UK practice. Sex Transm Infect. 2008;84(2):97-100. Epub 2007 Dec 12

54. Mercer $\mathrm{CH}$, Tanton C, Prah P, Erens B, Sonnenberg P, Clifton S, et al. Changes in sexual attitudes and lifestyles in Britain through the life course and over time: findings from the National Surveys of Sexual Attitudes and
Lifestyles (Natsal). Lancet. 2013;382(9907):1781-94. doi:10.1016/S01406736(13)62035-8. Epub 2013 Nov 26.

55. de Vries HJ, Zingoni A, White JA, Ross JD, Kreuter A, de Vries HJ, et al. 2013 European Guideline on the management of proctitis, proctocolitis and enteritis caused by sexually transmissible pathogens. Int J STD AIDS. 2013; 25(7):465-74 [Epub ahead of print].

56. Chan SY, Jose S, King R, Pakianathan MR, Sabin C, Sadiq ST, et al. How likely is environmental or patient cross-contamination of Chlamydia trachomatis DNA to lead to false positive results in patients attending our clinic? Sex Transm Infect. 2013;89(2):105-7. doi:10.1136/sextrans-2012-050667. Epub 2012 Oct 4.

57. Yeruva L, Spencer N, Bowlin AK, Wang Y, Rank RG. Chlamydial infection of the gastrointestinal tract: a reservoir for persistent infection. Pathog Dis. 2013;68(3):88-95. doi:10.1111/2049-632X.12052. Epub 2013 Jul 10.

58. Rank RG, Yeruva L. Hidden in plain sight: chlamydial gastrointestinal infection and its relevance to persistence in human genital infection. Infect Immun. 2014;82(4):1362-71. doi:10.1128/IAI.01244-13. Epub 2014 Jan 13. Review.

59. Schachter J, Grossman M, Holt J, Sweet R, Spector S. Infection with Chlamydia trachomatis: involvement of multiple anatomic sites in neonates. J Infect Dis. 1979;139(2):232-4.

60. Bissessor M, Tabrizi SN, Fairley CK, Danielewski J, Whitton B, Bird S, et al. Differing Neisseria gonorrhoeae bacterial loads in the pharynx and rectum in men who have sex with men: implications for gonococcal detection, transmission, and control. J Clin Microbiol. 2011;49(12):4304-6. doi:10.1128/ JCM.05341-11. Epub 2011 Sep 28

61. Kong FY, Tabrizi SN, Fairley CK, Vodstrcil LA, Huston WM, Chen M et al. The efficacy of azithromycin and doxycycline for the treatment of rectal chlamydia infection: a systematic review and meta-analysis. J Antimicrob Chemother. 2015. [Epub ahead of print]

62. Hocking JS, Kong FY, Timms P, Huston WM, Tabrizi SN. Treatment of rectal chlamydia infection may be more complicated than we originally thought. J Antimicrob Chemother. 2015;70(4):961-4. doi:10.1093/jac/dku493. Epub 2014 Dec 4.

63. Jordan SJ, Geisler WM. Azithromycin for rectal chlamydia: is it time to leave azithromycin on the shelf?... Not yet. Sex Transm Dis. 2014;41(2):86-8. doi: 10.1097/OLQ.0000000000000092.

64. Senior K. Chlamydia: a much underestimated STI. Lancet Infect Dis. 2012; 12(7):517-8.

65. Odesanmi TY, Wasti SP, Odesanmi OS, Adegbola O, Oguntuase OO, Mahmood S. Comparative effectiveness and acceptability of home-based and clinic-based sampling methods for sexually transmissible infections screening in females aged 14-50 years: a systematic review and metaanalysis. Sex Health. 2013;10(6):559-69. doi:10.1071/SH13029.

66. Theunissen KA, Hoebe CJ, Crutzen R, Kara-Zaïtri C, de Vries NK, van Bergen $J E_{\text {, et }}$ al. Using intervention mapping for the development of a targeted secure web-based outreach strategy named SafeFriend, for Chlamydia trachomatis testing in young people at risk. BMC Public Health. 2013;13:996. doi:10.1186/1471-2458-13-996.

67. Khosropour CM, Manhart LE, Colombara DV, Gillespie CW, Lowens MS, Totten PA, et al. Suboptimal adherence to doxycycline and treatment outcomes among men with non-gonococcal urethritis: a prospective cohort study. Sex Transm Infect. 2014;90(1):3-7. doi:10.1136/sextrans-2013-051174. Epub 2013 Oct 8.

68. Low N, Unemo M, Skov Jensen J, Breuer J, Stephenson JM. Molecular diagnostics for gonorrhoea: implications for antimicrobial resistance and the threat of untreatable gonorrhoea. PLoS Med. 2014;11(2):e1001598. doi:10. 1371/journal.pmed.1001598. eCollection 2014.

69. Barbee LA. Preparing for an era of untreatable gonorrhea. Curr Opin Infect Dis. 2014;27(3):282-7. doi:10.1097/QCO.0000000000000058.

70. Xiridou M, Soetens LC, Koedijk FD, Van der Sande MA, Wallinga J. Public health measures to control the spread of antimicrobial resistance in Neisseria gonorrhoeae in men who have sex with men. Epidemiol Infect. 2015;143(8):1575-84. doi:10.1017/S0950268814002519. Epub 2014 Oct 2.

71. Kohlhoff SA, Hammerschlag MR. Treatment of Chlamydial infections: 2014 update. Expert Opin Pharmacother. 2015;16(2):205-12. doi:10.1517/ 14656566.2015.999041.

72. Christiansen MT, Brown AC, Kundu S, Tutill HJ, Williams R, Brown JR, et al. Whole-genome enrichment and sequencing of Chlamydia trachomatis directly from clinical samples. BMC Infect Dis. 2014;14(1):591 [Epub ahead of print]. 
73. Althaus $\mathrm{CL}$, Turner $\mathrm{KM}$, Mercer $\mathrm{CH}$, Auguste $\mathrm{P}$, Roberts $\mathrm{TE}$, Bell $\mathrm{G}$, et al. Effectiveness and cost-effectiveness of traditional and new partner notification technologies for curable sexually transmitted infections: observational study, systematic reviews and mathematical modelling. Health Technol Assess. 2014;18(2):1-100. doi:10.3310/hta18020. vii-viii.

74. Dukers-Muijrers NH, Morré SA, Speksnijder A, van der Sande MA, Hoebe CJ. Chlamydia trachomatis test-of-cure cannot be based on a single highly sensitive laboratory test taken at least 3 weeks after treatment. PLoS ONE. 2012;7(3):e34108. doi:10.1371/journal.pone.0034108. Epub 2012 Mar 28.

75. Dukers-Muijrers NH, Speksnijder AG, Morré SA, Wolffs PF, van der Sande MA, Brink AA, et al. Detection of anorectal and cervicovaginal Chlamydia trachomatis infections following azithromycin treatment: prospective cohort study with multiple time-sequential measures of rRNA, DNA, quantitative load and symptoms. PLOS ONE. 2013;8(11):e81236. doi:10.1371/journal.pone. 0081236. eCollection 2013.

76. Craig AP, Kong FY, Yeruva L, Hocking JS, Rank RG, Wilson DP, et al. Is it time to switch to doxycycline from azithromycin for treating genital chlamydial infections in women? Modelling the impact of autoinoculation from the gastrointestinal tract to the genital tract. BMC Infect Dis. 2015;15(1):200. doi: 10.1186/s12879-015-0939-3.

77. Bernstein KT, Stephens SC, Barry PM, Kohn R, Philip SS, Liska S, et al. Chlamydia trachomatis and Neisseria gonorrhoeae transmission from the oropharynx to the urethra among men who have sex with men. Clin Infect Dis. 2009;49(12):1793-7. doi:10.1086/648427.

78. Marcus JL, Kohn RP, Barry PM, Philip SS, Bernstein KT. Chlamydia trachomatis and Neisseria gonorrhoeae transmission from the female oropharynx to the male urethra. Sex Transm Dis. 2011;38(5):372-3. doi:10.1097/OLQ. Ob013e3182029008.

79. Hui B, Fairley CK, Chen M, Grulich A, Hocking J, Prestage G et al. Oral and anal sex are key to sustaining gonorrhoea at endemic levels in MSM populations: a mathematical model. Sex Transm Infect. 2015. doi: 10.1136/ sextrans-2014-051760. [Epub ahead of print]

80. Vodstrcil LA, Mclver R, Huston WM, Tabrizi SN, Timms P, Hocking JS. The epidemiology of chlamydia trachomatis organism load during genital infection: A systematic review. J Infect Dis. 2014. [Epub ahead of print]

81. Dirks JA, Wolffs PF, Dukers-Muijrers NH, Brink AA, Speksnijder AG, Hoebe CJ. Chlamydia trachomatis Load in Population-Based Screening and STI-Clinics: Implications for Screening Policy. PLoS ONE. 2015;10(3):e0121433. doi:10. 1371/journal.pone.0121433.

82. Van Liere GAFS, Dirks JA, Hoebe JPA, Wolffs P, Dukers-Muijrers NHTM. Anorectal chlamydia load is similar in men who have sex with men and women reporting anal sex. PLOS ONE. 2015;10(8):e0134991. doi:10.1371/ journal.pone.0134991. eCollection 2015.

83. Bernstein KT, Marcus JL, Nieri G, Philip SS, Klausner JD. Rectal gonorrhea and chlamydia reinfection is associated with increased risk of HIV seroconversion. J Acquir Immune Defic Syndr. 2010;53(4):537-43.

84. Jin F, Prestage GP, Imrie J, Kippax SC, Donovan B, Templeton DJ, et al. Anal sexually transmitted infections and risk of HIV infection in homosexual men. J Acquir Immune Defic Syndr. 2010;53(1):144-9.

85. Pathela P, Braunstein SL, Blank S, Schillinger JA. HIV incidence among men with and those without sexually transmitted rectal infections: estimates from matching against an HIV case registry. Clin Infect Dis. 2013:57(8):1203-9.

86. Vaughan AS, Kelley CF, Luisi N, Del Rio C, Sullivan PS, Rosenberg ES. An application of propensity score weighting to quantify the causal effect of rectal sexually transmitted infections on incident HIV among men who have sex with men. BMC Med Res Methodol. 2015;15(1):25. doi:10.1186/s12874015-0017-y.

87. Chesson HW, Bernstein KT, Gift TL, Marcus JL, Pipkin S, Kent CK. The costeffectiveness of screening men who have sex with men for rectal chlamydial and gonococcal infection to prevent HIV Infection. Sex Transm Dis. 2013;40(5):366-71. doi:10.1097/OLQ.0b013e318284e544.

88. Vriend HJ, Lugnér AK, Xiridou M, van der Loeff MF S, Prins M, de Vries HJ, et al. Sexually transmitted infections screening at HIV treatment centers for MSM can be cost-effective. AIDS. 2013;27(14):2281-90. doi:10.1097/QAD. Ob013e32836281ee.

89. Hessol NA, Holly EA, Efird JT, Minkoff H, Weber KM, Darragh TM, et al. Concomitant anal and cervical human papillomavirus infections and intraepithelial neoplasia in HIV-infected and uninfected women. AIDS. 2013; 27(11):1743-51. doi:10.1097/QAD.0b013e3283601b09.
90. McGowin CL, Anderson-Smits C. Mycoplasma genitalium: an emerging cause of sexually transmitted disease in women. PLoS Pathog. 2011;7(5): e1001324. doi:10.1371/journal.ppat.1001324. Epub 2011 May 26.

91. Lillis RA, Nsuami MJ, Myers L, Martin DH. Utility of urine, vaginal, cervical, and rectal specimens for detection of Mycoplasma genitalium in women. J Clin Microbiol. 2011:49:1990-2.

\section{Submit your next manuscript to BioMed Central and take full advantage of:}

- Convenient online submission

- Thorough peer review

- No space constraints or color figure charges

- Immediate publication on acceptance

- Inclusion in PubMed, CAS, Scopus and Google Scholar

- Research which is freely available for redistribution 